\title{
Femina, RBG0 e o Ano 2000
}

\section{Colega,}

Neste início de ano, entre os bons fatos e as notícias alvissareiras para nós da FEBRASGO, uma merece atenção e destaque especial, pois representa o coroamento de uma longa, trabalhosa e qualificada caminhada. Falamos do papel que desempenham, na atualização dos ginecologistas e obstetras brasileiros, nossos dois peródicos, Femina e RBGO.

Femina, é a revista mais lida da especialidade há muitos anos. É a nossa "primeira dama", acompanhando e colaborando para a formação e informação de gerações de colegas. Mais tarde, surgiu RBGO, um periódico com outra proposição e, por isso, considerado mais científico por muitos. Enquanto Femina se caracteriza por artigos de revisão, por uma sessão "ciência e consciência", onde os associados podem publicar seus questionamentos sobre a especialidade e artigos de cunho prático, de aplicação imediata, em RBGO foi reservado espaço para publicações de pesquisas e de trabalhos originais, bem como para os resumos de dissertações e de teses.

No final de 1999, as estatísticas da "Pesquisa Data Folha" apontaram Femina como a revista mais lida da especialidade, seguida da RBGO, o segundo periódico mais consultado no Brasil. As duas revistas não são excludentes, mas complementares.

Por isso, neste inicio de 2000, estamos todos de parabéns. 